\title{
RECEPTORS FOR REPRODUCTIVE HORMONES
}




\section{ADVANCES IN EXPERIMENTAL MEDICINE AND BIOLOGY}

Editorial Board:

Nathan Back

N. R. Di Luzio

Alfred Gellhorn

Bernard Halpern

Ephraim Katchalski

David Kritchevsky

Nhel Lajtha

Rodolfo Paoletti
Chairman, Department of Biochemical Pharmacology, School of Pharmacy, State University of New York, Buffalo, New York

Chairman, Department of Physiology, Tulane University School of Medicine, New Orleans, Louisiana

University of Pennsylvania Medical School, Philadelphia, Pennsylvania

Collège de France,

Director of the Institute of Immuno-Biology, Paris, France

Department of Biophysics, The Weizmann Institute of Science, Rehovoth, Israel

Wistar Institute, Philadelphia, Pennsylvania

New York State Research Institute for Neurochemistry and Drug Addiction, Ward's Island, New York

Institute of Pharmacology and Pharmacognosy, University of Milan, Milan, Italy

\section{Volume 1}

THE RETICULOENDOTHELIAL SYSTEM AND ATHEROSCLEROSIS

Edited by N. R. Di Luzio and R. Paoletti 1967

Volume 2

IH.ARIICOLOGY OF HORMONAL POLYPEPTIDES AND PROTEINS

Edited by N. Back, L. Martini, and R. Paoletti 1968

Volume 3

GERM-FREE BIOLOG; : Expermental and Cilinıal Aspects

Edited by E. A. Mirand and N. Back $\bullet 1969$

Volume 4

DRUGS AFFECTING LIPID METABOLISM

Edited by W. L. Holmes, L. A. Carlson, and R. Paoletti 1969

Volume 5

LYMPHATIC TISSUE AND GERMINAL CENTERS IN IMMUNE RESPONSE

Edited by L. Fiore-Donati and M. G. Hanna, Jr. $\bullet 1969$

Volune 6

RED CELL METABOLISM AND FUNCTION

Edited by George J. Brewer 1970

Volume 7

SURFACE CHEMISTRY OF BIOLOGICAL SYSTEMS

Edited by Martin Blank 1970

Volume 8

BRADYKININ AND RELATED KININS: Cardiovascular, Biochemical, and

Neural Actions

Edited by F. Sicuteri, M. Rocha e Silva, and N. Back $\bullet 1970$

Volume 9

SHOCK : Biochemical, Pharmacological, and Clinical Aspects

Edited by A. Bertelli and N. Back $\cdot 1970$

Volume 10

THE HUMAN TESTIS

Edited by E. Rosemberg and C. A. Paulsen 1970

Volume 11

MUSCLE METABOLISM DURING EXERCISE

Edited by B. Pernow and B. Saltin $\cdot 1971$

Volume 12

MORPHOLOGICAL AND FUNCTIONAL ASPECTS OF IMMUNITY

Edited by K. Lindahl-Kiessling, G. Alm, and M. G. Hanna, Jr.・1971 
Volume 13

CHEMISTRY AND BRAIN DEVELOPMENT

Edited by R. Paoletti and A. N. Davison $\cdot 1971$

Volume 14

MEMBRANE-BOUND ENZYMES

Edited by G. Porcellati and F. di Jeso • 1971

Volume 15

THE RETICULOENDOTHELIAL SYSTEM AND IMMUNE PHENOMENA

Edited by N. R. Di Luzio and K. Flemming $\bullet 1971$

Volume 16A

THE ARTERY AND THE PROCESS OF ARTERIOSCLEROSIS: Pathogenesis

Edited by Stewart Wolf $\cdot 1971$

Volume 16B

THE ARTERY AND THE PROCESS OF ARTERIOSCLEROSIS: Measurement and

Modification

Edited by Stewart Wolf 1971

Volume 17

CONTROL OF RENIN SECRETION

Edited by Tatiana A. Assaykeen $\bullet 1972$

Volume 18

THE DYNAMICS OF MERISTEM CELL POPULATIONS

Edited by Morton W. Miller and Charles C. Kuehnert $\bullet 1972$

Volume 19

SPHINGOLIPIDS, SPHINGOLIPIDOSES AND ALLIED DISORDERS

Edited by Bruno W. Volk and Stanley M. Aronson $\bullet 1972$

Volume 20

I)RUG ABLSE: Nonmedical Use of Dependence-Producing Drugs

Edited by Simon Btesh $\bullet 1972$

Volume 21

VASOPEPTIDES: Chemistry, Pharmacology, and Pathophysiology

Edited by N. Back and F. Sicuteri $\cdot 1972$

Volume 22

COMPARATIVE PATHOPHYSIOLOGY OF CIRCULATORY DISTURBANCES

Edited by Colin M. Bloor $\bullet 1972$

Volume 23

THE FUNIDAMENTAL MECHANISNIS OF SHOC:K

Edited by Lerner B. Hinshaw and Barhara (;. Cox • 1972

Volume 24

THE VISUAL SYSTEM: Neurophysiology, Biophysics, and Their Clinical Applications Edited by (;. B. Arden 1972

Volume 25

GLYCOLIPIDS, GLYCOPROTEINS, AND MUCOPOLYSACCHARIDES

OF THE NERVOUS SYSTEM

Edited by Vittorio Zambotti, Guido Tettamanti, and Mariagrazia Arrigoni • 1972

Volume 26

PHARMACOLOGICAL CONTROL OF LIPID METABOLISM

Edited by William L. Holmes, Rodolfo Paoletti, and David Kritchevsky $\bullet 1972$

Volume 27

DRUGS AND FETAL DEVELOPMENT

Edited by M. A. Klingberg, A. Abramovici, and J. Chemke $\bullet 1973$

Volume 28

HEMOGLOBIN AND RED CELL STRUCTURE AND FUNCTION

Edited by George J. Brewer $\bullet 1972$ 
Volume 29

MIC.ROENVIRONMENTAL ASPECTS OF IMMUNITY

Edited by Branislav D. Janković and Katarina Isaković $\bullet 1972$

Volume 30

HUMAN DEVELOPMENT AND THE THYROID GLAND: Relation to Endemic C'retinism

Edited by J. B. Stanbury and R. L. Kroc $\bullet 1972$

Volume 31

IMMUNITY IN VIRAL AND RICKETTSIAL DISEASES

Edited by A. Kohn and M. A. Klingberg $\bullet 1973$

Volume 32

FUNCTIONAL AND STRUCTURAL PROTEINS OF THE NERVOUS SYSTEM

Edited by A. N. Davison, P. Mandel, and I. G. Morgan $\bullet 1972$

Volume 33

NEUROHUMORAL AND METABOLIC ASPECTS OF INJURY

Edited by A. G. B. Kovach, H. B. Stoner, and J. J. Spitzer $\bullet 1972$

Volume 34

PLATELET FUNCTION AND THROMBOSIS: A Review of Methods

Edited by P. M. Mannucci and S. Gorini $\bullet 1972$

Volume 35

ALCOHOL INTOXICATION AND WITHDRAWAL: EXPERIMENTAL STUDIES

Milton M. Gross $\bullet 1973$

Volume 36

RECEPTORS FOR REPRODUCTIVE HORMONES

Bert W. O'Malley and Anthony R. Means • 1973 


\section{RECEPTORS FOR REPRODUCTIVE HORMONES}

Edited by

Bert W. O'Malley

and Anthony R. Means

Department of Cell Biology

Baylor College of Medicine

Houston, Texas

PLENUM PRESS • NEW YORK-LONDON • 1973 
Proceedings of the Workshop Conference held at Vanderbilt University, Nashville, Tennessee, July 10-11, 1972, sponsored by the Center for Population Research, National Institute of Child Health and Human Development

Library of Congress Catalog Card Number 73-81095

ISBN 978-1-4684-3239-8

ISBN 978-1-4684-3237-4 (eBook)

DOI 10.1007/ 978-1-4684-3237-4

(c) 1973 Plenum Press, New York

Softcover reprint of the hardcover 1st edition 1973

A Division of Plenum Publishing Corporation

227 West 17th Street, New York, N. Y. 10011

United Kingdom edition published by Plenum Press, London

A Division of Plenum Publishing Company, Ltd.

Davis House (4th Floor), 8 Scrubs Lane, Harlesden, London NW 10 6SE, England

All rights reserved

No part of this publication may be reproduced in any form without written permission from the publisher 
PREFACE

We are especially grateful to Dr. Philip Corfman and his colleagues of the Population and Reproduction Grants Branch of NICHD for making this Conference possible. The format of this volume follows in general the order in which the papers were presented during the Conference. The Conference was divided into four sessions, each of which was presided over by a capable and distinguished scientist. Each of these chairmen, Drs. T. H. Hamilton, G. A. Puca, R. I. Vande Wiele and H. G. Williams-Ashman provided valuable discussion and for their services we are most appreciative.

The Editors are indebted to $\mathrm{Mr}$. Robert Colligan for his help in organizing and in redacting the manuscripts. A special commendation is also extended to Ms. Mary Jane Fowler who cheerfully and efficiently typed this entire volume.

Finally, we express thanks to the individual participants of the Conference for their cooperation and prompt submission of the manuscripts and to the Plenum Press for ensuring the rapid publication of this volume.

Anthony R. Means, Ph.D.

Bert W. O'Malley, M. D.

March, 1973 
FOREWORD

This book emanates from the Conference on Receptors for Reproductive Hormones supported by the Center for Population Research, National Institutes for Child Health and Human Development and held at Vanderbilt University in July, 1972, in conjunction with the second annual meeting of Directors of CPR-supported population research centers and program projects. The Conference theme of "Receptors for Reproductive Hormones" was considered to be a timely topic due to the intensity of current research interest in this field, the abundance of new data and mechanistic concepts, the significant amount of support provided by the Center for Population Research to a large number of investigators in this area, and the relevance of this field to design and development of new contraceptive agents.

The program of speakers included many of the major international investigators in this field and dealt with both sex steroid and gonadotrophin receptors. It was quite evident from the presentations and discussions that current progress continues to be both rapid and imaginative. New data were presented for open discussion and criticism on: equilibrium kinetics for the relocation of the sex steroid receptor from the target cell cytoplasm to nucleus; binding of nuclear receptor to chromosomal proteins and DNA, including specific roles for receptor subunits; alterations in nuclear RNA synthesis induced by receptors; correlation of nuclear receptor content with biologic effects; recycling of receptors in target cells; elucidation of gonadotrophin receptor sites on target cell membrane; uterine adenylate cyclase and CAMP responsive systems; activation of adenylate cyclase by the interaction of gonadotrophins with their membrane receptors; and mathematical theories of hormone-receptor interaction. Comparisons were made for estrogens, progestins, androgens, and gonadotrophins in normal and neoplastic cells of multiple target tissues and in a number of animal species, including human.

The known attitude of investigators in this field of "Receptors and Hormone Action" to discuss current data and concepts in a frank and friendly manner was again as evident at this meeting as on previous occasions. We honestly feel that the warm relationships developed over the past decade among workers in this area of investigations cannot help but facilitate more rapid scientific progress. 
In summary, the conference seemed to clearly point out the level of progress achieved in this field over the past decade and the biological relevance of receptors to the mechanism of action of sex steroids and gonadotrophins. It appeared quite probable that continued scientific advancement in this area may not only lead to a better understanding of basic aspects of cell and reproductive biology but in addition, may provide new insights for antihormones and development of new contraceptive compounds.

Bert W. O'Malley, M. D.

Anthony R. Means, Ph.D.

March, 1973 


\section{CONTENTS}

The Continuing Evolution of an Estrogen-Receptor Model . . . . I Jack Gorski, David Williams, George Giannopoulos, and George Stancel

Nuclear Receptor Estrogen Complexes of Rat Uteri: Concentration-Time-Response Parameters . . . . . . 15 J. H. Clark, J. N. Anderson, and E. J. Peck, Jr.

Estrogen Receptor Transformation and Nuclear RNA Synthesis . . 60 Elwood V. Jensen, Suresh Mohla, Peter I. Brecher, and Eugene R. DeSombre

Estradiol Receptors: A New Evaluation . . . . . . . . . 80 E. E. Baulieu

The Interaction of Uterine Estrogen Receptors with DNA . . . 85 D. Toft

Estrogen Binding in the Rat and Human . . . . . . . . . . . . 97

P. K. Siiteri, R. E. Schwartz, I. Moriyama, R. Ashby,

D. Linkie, and P. C. MacDonald

Studies on the Estrogen Receptor in Breast Cancer . . . . . 113 W. L. McGuire and G. C. Chamness

Studies on Androgen and Estrogen Uptake by Rat Hypothalamus. . 137 Marietta Vertes, Ayalla Barnea, H. R. Lindner, and R. J. B. King

Hormone - Receptor Interactions with the Genome of Eucaryotic Target Cells .................. . 174 Bert W. O'Malley, William T. Schrader, and Thomas C. Spelsberg 
A Review of Current Research on the Binding and Mechanism of Action of Androgenic Steroids, Notably

5a-Dihydrotestosterone . . . . . . . . . . . 197

W. I. P. Mainwaring, F. R. Mangan, P. A. Wilce, and

E. G. P. Milroy

Androgen - Receptor Cycling in Prostate Cells . . . . . . . 232 Shutsung Liao, Tehming Liang, T.-C. Shao and

J. L. Tymoczko

Adenyl Cyclase and the Cyclic AMP Responsive Systems in

the Uterus.................. . 241 Stanley G. Korenman, Barbara M. Sanborn, and

Ramesh C. Bhalla

Affinity Labeling Steroids for Characterization of Steroid

Binding Sites . . . . . . . . . . . . 263

James C. Warren

Mathematics of Hormone - Receptor Interaction

D. Rodbard

I. Basic Principles . . . . . . . . 289

Theory of Radioimmunoassays and Hormone - Receptor

Interactions :

II. Simulation of Antibody Divalency, Cooperativity

and Allosteric Effects . . . . . . . . . . 327

D. Rodbard and R. E. Bertino

Theory of Hormone - Receptor Interaction

III. The Endocrine Target Cell as a Quantal

Response Unit: A General Control Mechanism . . . 342

D. Rodbard

Autoradiographic Analysis of Gonadotropin Binding to Rat

Ovarian Tissue Sections .......... 365

A. Rees Midgley, Jr.

Interactions of LH and hCG with Testicular Gonadotropin

Receptors . . . . . . . . . . . 379

K. J. Catt and M. L. Dufau

Luteinizing Hormone Receptors in Luteinized Rat Ovaries . . 419

C. Y. Lee and R. J. Ryan

Specific Interaction of $3 \mathrm{H}-\mathrm{FSH}$ with Rat Testis Binding

Sites .. . . . . . . . . . . . 431

Anthony R. Means

Index 